\title{
Effect of Government Expenditure Components on Agricultural Productivity in Nigeria (1981-2017)
}

\author{
Olasusi Akinwale Akodu Patrick Ayodele \\ Department of Economics, Obafemi Awolowo University, Ile-Ife, Nigeria
}

\begin{abstract}
We analyzed the relationship between government expenditure components and agricultural productivity in Nigeria by estimating the effects and their causal interaction over the period 1981-2017. The study employed the Autoregressive Distributed Lag (ARDL) technique to identify the existence of cointegration while going further by estimating the short and long run effects of government expenditure components on agricultural productivity as well as the Granger causality and Block Exogeneity tests under the Vector Autoregressive (VAR) models to analyze their causal relationship. Data were sourced from the Central Bank Statistical Bulletin, 2017 edition. The ARDL results revealed that there exists a long run relationship among the variables and showed that various components of government expenditure can positively improve agricultural productivity in Nigeria, but the current effects of these variables on agricultural productivity appears insignificant. The results revealed that the government expenditures on health and infrastructure have little effect on agricultural productivity and expenditures on education have a reduction effect on agricultural productivity in both short and long runs in Nigeria; highlighting the disconnection between agricultural knowledge acquisition and its implementation. Causality tests also showed that expenditures on education, health and infrastructure can help improve agricultural productivity in Nigeria. The study recommended effective policy implementation through a complete overhaul of the various government institutions and agencies responsible for implementation, revenue collection and monitoring of government project as it relates to agricultural development as well as encourage effective manpower development in the agricultural sector to boost productivity.
\end{abstract}

Keywords: Agricultural credit; Agriculture productivity; Autoregressive Distributed Lag, Government Expenditure, Inflation; Vector Autoregressive model.

DOI: $10.7176 / \mathrm{JESD} / 10-18-01$

Publication date:September $30^{\text {th }} 2019$

\subsection{Introduction}

The importance of agriculture to every economy cannot be understated or overemphasized. This relevance cut across tribal, religious or social beliefs or attributes of the people. Even right before the discovery of oil in the early 1960s, the oil boom of the 1970s and till date, agriculture has remained an important economic nerve-center to Nigerian economic development. This role is enormous since agriculture is undoubtedly the main source of food and employment for the largest part of the population. It also provides raw materials for most of the industries in the country and income for individuals and the government. In the 1960 s, over $80 \%$ of the rural Nigerian population was engaged in different types of agricultural activity and between 1963 and 1964; the sector contributed more than 65\% of the nation's Gross Domestic product (GDP) (Yesufu 1996, Anyanwu et al 1997). But recently, these roles seem to elude the country due to the neglects resulting from the dependence on oil since the oil boom of 1990s; the global economic crisis of the 1980s resulting from the deterioration in the nation's terms of trade, and the continuous reduction in government finance to the sector (Iwayemi 1994, Ijaiya 2000). Although Nigeria has been an agrarian economy with this serving as the main source of growth and income, agricultural sector have been unable to play this role in recent years, even since independence. This is because agricultural financing have been relegated to the backward end despite the huge revenue been generated from oil, resulting into a critical malfunctioning of the Nigeria's agricultural sector (Oji-Okoro, 2011; Hammond, 2003).

In many developing economies, agriculture sector remains the largest sector judging from its share in the nation's Gross Domestic Product (GDP), employment and more importantly, majority of the people in these countries resides in the rural areas and has agriculture as the main source of their livelihood. Hence, agriculture plays critical role in achieving economic growth, development and reducing poverty (Armas et al. 2012). However, to revive the current poor state of agricultural contribution to growth in Nigeria, government spending remains one of the important policy tools of government for useful for promoting overall economic rejuvenation and the alleviation of poverty (Ayoola and Oboh, 2000; Diao et al. 2009 among others). But reality seem to portray the failure of government expenditures in impacting positively on productivity of agriculture in Nigeria as the yearly increase in government fiscal allocation to agriculture does not seem to yield to productivity increase while foreign firm investments contribute more to agricultural productivity in Nigeria than the local firms, government and individual investments. (Ayanwale and Bamire, 2004; Iganiga and Unemhilin, 2011; Ani 2014).

A detailed analysis of government fiscal spending on agriculture sector in Nigeria revealed an underfunded sector that still strive to contribute significantly to general economic wellbeing. In 1978, government fiscal 
spending on agriculture was a paltry $1.67 \%$ of total government expenditure. It increased to $2.50 \%, 4.59 \%$ in 1983 and 1989 respectively while declining to $1.90 \%, 0.559 \%$ in 1995 and 1996 respectively. In 2005, it increased again to $3.99 \%$ and further to $5.28 \%$ in 2008 . Thus, the share of government fiscal spending on agriculture has been fluctuating and inconsistent. It must be noted that public spending remains one major and effective tool for improving agricultural growth as the sector plays prominent role in the process of achieving poverty reduction in developing countries. Thus, it become important to empirically explore public spending contribution and to agriculture and how such contribution have been affecting the sector over the years.

Agricultural growth also depends on non-agriculture expenditures such as rural infrastructure, health and education. Though these investments could have differential productivity impact, it however still plays important role for monitoring spending in this sector, as agricultural progress centrally align with infrastructural, health and educational improvement of the citizenry (Shenggen et al (2009)).

On the other hand, the share of agricultural productivity in the total Gross Domestic Product (GDP) of the Nigerian economy revealed an increasing trend. A 1978 value of $23.28 \%$ increased further to $33.21 \%$ in 1983 which further increased to $40.60 \%$ in $1988,48.57 \%$ in 2002 before declining to $32.85 \%$ in 2008 . Thus, the decline experienced from 2002 shows a high inconsistency in government's agricultural policies in Nigeria.

Several factors were seen as factors that enhance or retard growth in the agricultural sector. These factors included education (Huffman 1949; Pudasini 1983; Akeem et al. 1998; Weir 1999), infrastructure (Quevioz and Gaultam 1993; Gopinath and Roe 1997; Yee et al. 2000 and VenkAtachalam 2003) and inflation (Johnson 1980; Bullard and Keating 1995, Gokal and Hanif 2004). Others factors may include credit to the sector and rainfall. Empirical studies on the quantitative analysis of economic determinants of agricultural output are few. The few studies focused on the direct impact of these factors mentioned without recourse to the impact of the fiscal policies relating to them factors on agricultural productivity, a gap which this study fills.

\subsection{Literature Review}

\subsection{Theoretical Framework}

The study on the relationship between government expenditure and economic growth has its theoretical basis from endogenous growth theory (Barro, 1990). However, endogenous growth theory mainly aimed to model technology rather than assuming it to be exogenous. Economic growth remains a function of technological progress which is the essential ability of an economic unit to make use of its productive resources in an effectual manner over time. Much of this ability originates from the process of learning to operate newly created production equipment in a more efficient way or more from understanding how to cope with rapid changes in the production structure which implies industrial progress must. Peradventure if output is to increase year by year, the economy must continually provide the workforce with more equipment. By equipment, the theorists refer to a very broad concept of reproducible capital which includes physical capital, human capital and knowledge capital. Past development experiences show that economies differ with respect to their abilities to learn how to absorb new techniques and how to adjust quickly to new lines of production.

The previous literature likes Barro (1990), Barrow Sala-i-Martin (1992) and Easterly and Rebelo (1993) on endogenous economic growth gives room for effect of fiscal policy on long-term growth. This theory directs our focus to the only way by which government can affect long run growth, via its investment impact on physical capital, human capital and technical knowledge. Public expenditures determine such investments by generating additional marginal tax wedge over those induced by the taxes required financing these programs, or that reduce incentives to save and accumulate capital in other ways, reduce growth as per these models (Folster and Henrekson, 1999). Therefore, the distinguishing characteristic of the public-policy endogenous growth model is that government expenditures can determine both the level of output pathway and the steady-state growth level. In this case only the flow of public expenditure is considered in the model as follows;

$y_{t}=f\left(A, K_{t}, L_{t}\right)$

Where $y$ is aggregate real productivity, $\mathrm{K}$ represents stock of capital, L represents labour stock, A represents technology.

So using a Cobb Douglas production function as a specific form of the above function, we have;

$$
y_{t}=A K_{t}^{\alpha} L_{t}^{1-\alpha}
$$

Linearizing the above equation and expressing it explicitly, we have;

$$
\operatorname{Ln} y_{t}=\operatorname{Ln}(A)+\alpha \operatorname{Ln}\left(K_{t}\right)+(1-\alpha) \operatorname{Ln}\left(L_{t}\right)
$$

Introducing an error term into equation (2), the model them becomes;

$$
\left.\operatorname{Ln} Y_{t}=\operatorname{Ln}(A)+\alpha \operatorname{Ln}\left(K_{t}\right)+(1-\alpha) \operatorname{Ln}\left(L_{t}\right)+\varepsilon_{t}\right)
$$

\subsection{Empirical Literature}

Empirically, various studies have looked into the interaction of government fiscal policy variables and agricultural development. few of this studies have focused on the role which general government expenditure aggregation have played in influencing the level of productive performance of this sector while some majored on the role of budget 
and budgetary allocation in encouraging agricultural expansion majorly at regional and international levels. However, there seems no consistent evidence that supports significant relationship between public expenditure components and agricultural output growth in Nigeria, either in positive or negative direction. Results and evidence about the effect of government spending on agricultural output growth differ by country, analytical method employed, and categorization of public expenditures. The focus of this brief review shall therefore be on developing countries and Nigerian economy, on which this study is based. Beginning with the study of Chavas (2001), the study used FAO annual data on agricultural inputs and outputs for twelve developing countries between 1960 and 1994. Technical efficiency indices for time series analysis results showed that in general, the technology of the early 1990s was in several ways related to the one in the early $1960 \mathrm{~s}$, revealing that the improvement in agricultural production was not because of technology but because of other inputs such as fertilizer and pesticides. Concluding, the study showed much evidence of strong productivity growth in agriculture over the last few decades corresponding to changes in inputs. Also, Shenggen et al (2009) studied the trends and composition of agricultural spending in developing countries, identifying growing trends of agricultural expenditure in the sub-Saharan Africa over the years. It found that the developing economies spend more on agricultural production than the developing countries, hence the more reason why the developed economies achieve higher agricultural productivity than the developing economies. With $70 \%$ and above of the population in Africa involved in agricultural production, the economies in Africa have a higher productivity tendency if more focus is paid towards encouraging mechanized agriculture through the aid of improved government expenditure.

Similar studies on the contributory effect of factors of production to agricultural productivity include Velasco (2001); Tripathy (2008); Kiani et al (2008); introduces a dimensional view of agricultural productivity growth in India. Thestudy also analyzed the impact of the various factors of production on agricultural productivity growth between 1967-2006. Basing its analyses on Cobb-Douglas production function theoretical framework, the results showed that output elasticity of land was 1.98 , labour 1.06 and capital 0.15 and when added up they gave a sum greater than one. This meant that all inputs had positive and significant effect on agricultural productivity growth. It was also found that improving labour, capital and land productivity can improve agricultural productivity. Kiani et al (2008) which measured total factor productivity of the crop production and analyzed the relationship between productivity and agricultural research expenditures during 1970-2004 in Pakistan using Tornqvist-Therl index method for measuring total factor productivity and outputs/input for 24 fields and horticulture crops found that total productivity index for crops sub-sector improved over time, at an average annual growth rate of $2.2 \%$. Among the reasons for this improvement was the growth in productivity over the previous 35 years. It was concluded that agricultural research investment played an important role in productivity growth and also, mechanization and development of roads infrastructure also had a positive and significant effect on total factor productivity.

Various other studies also well more on agricultural pricing, investments and financing on agricultural output. Ranging from the works of Nlandu (1996); Wiebe et al (2001); Zepeda (2001); Ayanwale and Bamire (2017) among others, emphasi

zed the important role of agricultural financing in improving agricultural productivity. These studies also dwell more on $\mathrm{k}$ understanding the quantitative dimensions of agricultural supply as issues relating to data pooling, omission of variables, foreign direct investments and asymmetry supply in response to price changes were adequately dealt with. The study majorly found that farmers normally respond to increase in output and also respond to increase in funding by increasing productivity. However, unfavorable pricing was identified as a major hindrance to agricultural output growth.

Furthermore in Nigeria, there is an extensive debate over the relationship between government revenue and expenditure and their effect on agricultural productivity. Before the attainment of independence, agriculture was identified as an important factor, which helped to achieve a relative level of economic diversification and capably placing Nigeria on the part of economic development. The colonial administration in realizing this, set up marketing boards for the major cash crops. The stringent growth the nation was gradually experiencing then began deflating upon the discovery of oil (Oyelami and Alege, 2018). Heilleiner (1966) emphasized that export production accounted for about $57 \%$ of Nigeria's Gross Domestic product in 1929. The contribution of the sector to the GDP continued to increase. Agriculture even became the leading sector in Nigeria's economy in 1950s and 1960s. Agricultural output accounted for 62 and 54 percent GDP within these periods (Aigbokhan 2001). The advent of oil in the 1970s, reduced agricultural contribution to GDP to 33.2\%. This period through the 1973/1974 (crude oil price shocks) is an important period in Nigeria's economic history.

Studies by Nwosu (2004); Akpodjie and Nwosu (1993); Onanukwe (2005); FAO (2008) posited that government have been the major financier of agriculture in Nigeria and that government has endeavored to improve her expenditure on agriculture through budgetary allocation and through the provision of cheap and readily available credit facilities but these funding have been highly inadequate and still fell short of what Food and Agricultural Organization (FAO) recommended that $25 \%$ of government capital budget be allocated to the agricultural development in promoting agricultural productivity within the economy. Onanukwe (2005) further posited that large amount of the funds for agricultural expansion does not go directly to the farmers. 
The DFID further buttressed this fact in her report in 2005 that the largest part of private investors in Nigerian agriculture sector consists of the small holder farmers scattered all over the country. Hence agricultural production in Nigeria is most populated by small-scale farms characterized by small, uneconomic and mostly fragmented holdings, mostly involved in subsistence farming with less capacity for mass production. The resultant effect is poersistent low productivity, low income and low capital investment.

While several studies as reviewed above have blamed funding inadequacies among other factors as the primary reason for agricultural backwardness in Nigeria, other studies like Eyo (2008) and Amassoma et al (2011); Vida et al (2009); Suleiman and Aminu (2012); Adofu et al (2012) among others emphasized the paramount role of agricultural finance in promoting agricultural output and also believe that agricultural output improvement could result into improvement in the gross domestic product level even within the short run period. But the studies decried the role played by institutional factors and organizational bottlenecks in hampering the rate of growth and expansion of the sector in Nigeria. They also believed that there is a huge gap in policy implementation and monitoring within the Nigerian agricultural environment which have led to a persistent misuse of funds and inputs allocated for agricultural expansion.

\subsection{Research Methodology}

This study examines effect of various components of government expenditure on agricultural output growth in Nigeria. The model for this study follows the endogenous growth model extending from the theoretical framework above, where changes in output are a function of technology, capital and labour. According to Barro (1990), Barrow Sala-i-Martin 1992), endogenous growth theory directs our attention to the fact that the only way by which government can affect long run growth is via its expenditure. Extending the model (4) to our study where we assumed government expenditure as being the sole determinant of output, this can be represented as;

$\mathrm{AOP}=\mathrm{f}(\mathrm{GE}, \mathrm{Z})$

Where AOP is the agricultural output, GE is government expenditure and $\mathrm{Z}$ represents other variables in the model. By linearising equation 4 above, it becomes

$a q_{t}=\alpha_{0}+\alpha_{1}$ ge $_{t}+\alpha_{2} z_{t}$

Where the variables are in $\log$ form, aq $=$ Agricultural output, $\alpha_{0}=$ Intercept, $\alpha_{1}=$ Estimation coefficient, $g e=$ Government spending components and $\varepsilon_{\mathrm{t}}=$ error term. The above model is an empirical model having appended

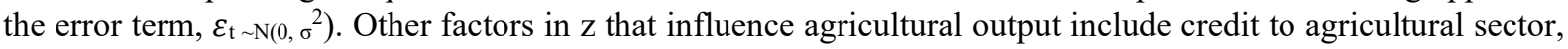
inflation rate. Rewriting eq(6), it becomes

$$
a q_{t}=\alpha_{0}+\alpha_{1} \text { geh }_{t}+\alpha_{2} \text { gei }_{t}+\alpha_{3} \text { gee }_{t}+\alpha_{4} \operatorname{cras}_{t}+\alpha_{5} \text { infl }_{t}+\varepsilon_{t}
$$

Where $\alpha_{0}$ is the intercept, geh $h_{t}$ is the government spending on health, gei $i_{t}$ is the government infrastructural expenditure, gee ${ }_{t}$ is the government educational expenditure, $\operatorname{cras}_{t}$ is the credit to agricultural sector, infl $l_{t}$ is the inflation rate.

In order to look at the differential effects of fiscal policy component, government expenditure is disaggregated into health, infrastructure and education expenditures as this decomposition of fiscal policy variable will help to assess the effects of fiscal policy shocks better on agricultural output. Utilising the Auto Regressive Distributed Lag (ARDL) procedure developed by Pesaran and Pesaran (1997), Pesaran and Shin (1999), Pesaran et al. (2000, 2001) to investigate the co-integration relationship between quantity of agricultural output and government spending and other variables, the study enjoys the better advantages of this technique over other techniques. Using annual data between 1981 to 2017, we have sufficiently large enough data points required for the model estimation and also provide opportunity to cater for the period when there is a sizeable improvement in government allocations to agricultural sector through oil revenue boom. The error correction model (ECM) was derived from ARDL through a simple linear transformation (Banerjee et al., 1993).

The ARDL model used for estimation is given as follows:

$$
\begin{aligned}
& \left\{\Delta \ln A O P_{t}\right\}=\phi_{0}+\sum_{j=1}^{p} \theta_{j} \Delta \ln A O P_{t-j}+\sum_{j=1}^{p} \Omega_{j} \Delta \ln G E H_{t-j}+ \\
& \sum_{j=1}^{p} \beta_{j} \Delta \ln G E E_{t-j}+\sum_{j=1}^{p} \Phi_{j} \Delta \ln G E I_{t-j}+\sum_{j=1}^{p} \pi_{j} \Delta C R A S_{t-j}+\sum_{j=1}^{p} \eta_{j} \Delta I N F L_{t-j} \\
& \left.+\varphi \ln A O P_{t-1}+\rho \ln G E H_{t-1}+\chi \ln G E E_{t-1}+\delta \ln G E I_{t-1}+\gamma \ln C R A S_{t-1}+\omega \ln I N F L_{t-1}+\varepsilon_{t}\right\}
\end{aligned}
$$

$\Phi_{0}$ is the constant and $\varepsilon_{\mathrm{t}}$ is the white noise error term, the error correction dynamics is represented by summation sign while the other side of the equation corresponds to long-run relationship. The null hypothesis of no cointegration is $\left(\mathrm{H}_{0:} \theta_{1}=\theta_{2}=\theta_{3}=\theta_{4}=\theta_{5}=\theta_{6}=0\right)$, on the other hand, the alternative hypothesis is represented as $\left(\mathrm{H}_{1}: \theta_{1 \neq} 0, \theta_{2 \neq} 0 \ldots \ldots \ldots \ldots \theta_{6 \neq}\right)$. The null hypothesis of no cointegration will be rejected if the calculated Ftest statistics exceeds the upper critical bound (UCB) value. The results are however seen to be inconclusive if the F-test statistics is below the lower critical bound. Also, the null hypothesis of no cointegration is accepted if the F-statistics is below the lower critical bound. On the other hand, if long-run relationship between government 
spending and agricultural output is found, then we estimate the long-run coefficients. The following model will be estimated the long-run coefficients.

$$
A O P_{t}=\beta_{0}+\beta_{1} \Sigma_{t=1}^{p} \mathrm{AOP}_{t-1}+\beta_{2} \Sigma_{t=1}^{p} \mathrm{GEH}_{t-1}+\beta_{3} \Sigma_{t=1}^{p} \mathrm{GEE}_{t-1}+\beta_{4} \Sigma_{t=1}^{p} G E I_{t-1}+\beta_{5} \Sigma_{t=1}^{p} I N F L_{t-1}+\varepsilon_{t}
$$

(9)

Finding of evidence of long-run relationship between government expenditure and agricultural output enables us to estimate the short-run coefficients by employing the following model.

$$
\begin{aligned}
& \Delta\left(\mathrm{AOP}_{t}\right)=\alpha_{0}+\sum_{k=1}^{p} \alpha_{1} \Delta\left(A O P_{t-k}\right)+\sum_{k=1}^{p} \alpha_{2} \Delta\left(G E H_{t-k}\right)+\sum_{k=1}^{p} \alpha_{3} \Delta\left(G E E_{t-1}\right) \\
& +\sum_{k=1}^{p} \alpha_{4} \Delta\left(G E I_{t-k}\right)+\sum_{k=1}^{p} \alpha_{5} \Delta\left(\mathrm{CRAS}_{t-k}\right)+\sum_{k=1}^{p} \alpha_{6}\left(\mathrm{INFL}_{t-k}\right)+\Omega \mathrm{ECM}_{t-1}+\varepsilon_{t}
\end{aligned}
$$

The error correction term (ECM) measures the speed of adjustment needed to restore the long-run equilibrium following a short-run shock. The ' $\Omega$ is the coefficient of error correction term in the model above which indicates the speed of adjustment. This equation includes both short and long run specifications. For the short run coefficients, each lag length $\mathrm{n}$ is chosen by minimizing the Akaike Information Criterion (AIC) and the model is estimated at this optimum lags.

In order to determine the causal relationship among the various components of government expenditure and agricultural productivity in Nigeria, the study estimates the following system of equations;

$$
\begin{aligned}
& A O P_{t}=\alpha_{1}+\sum_{j=1}^{k} \delta_{1 j} A O P_{t-j}+\sum_{j=1}^{k} \delta_{2 j} G E E_{t-j}+\sum_{j=1}^{k} \delta_{3 j} G E H_{t-j}+\sum_{j=1}^{k} \delta_{4 j} G E I_{t-j}+\sum_{j=1}^{k} \delta_{5} C R A S_{t-j}+\varepsilon_{1, t} \\
& G E E_{t}=\alpha_{2}+\sum_{j=1}^{k} \beta_{1 j} G E E_{t-j}+\sum_{j=1}^{k} \beta_{2 j} A O P_{t-j}+\sum_{j=1}^{k} \beta_{3 j} G E H_{t-j}+\sum_{j=1}^{k} \beta_{4 j} G E I_{t-j}+\sum_{j=1}^{k} \beta_{5} C R A S_{t-j}+\varepsilon_{2, t} \\
& G E H_{t}=\alpha_{3}+\sum_{j=1}^{k} \gamma_{1 j} G E H_{t-j}+\sum_{j=1}^{k} \gamma_{2 j} G E E_{t-j}+\sum_{j=1}^{k} \gamma_{3 j} A O P_{t-j}+\sum_{j=1}^{k} \gamma_{4 j} G E I_{t-j}+\sum_{j=1}^{k} \gamma_{5} C R A S_{t-j}+\varepsilon_{3, t}
\end{aligned}
$$

$$
G E I_{t}=\alpha_{4}+\sum_{j=1}^{k} \eta_{1 j} G E I_{t-j}+\sum_{j=1}^{k} \eta_{2 j} G E E_{t-j}+\sum_{j=1}^{k} \eta_{3 j} A O P_{t-j}+\sum_{j=1}^{k} \eta_{4 j} G E H_{t-j}+\sum_{j=1}^{k} \eta_{5} C R A S_{t-j}+\varepsilon_{4, t}
$$

$$
C R A S_{t}=\alpha_{5}+\sum_{j=1}^{k} \rho_{1 j} C R A S_{t-j}+\sum_{j=1}^{k} \rho_{2 j} G E I_{t-j}+\sum_{j=1}^{k} \rho_{3 j} A O P_{t-j}+\sum_{j=1}^{k} \rho_{4 j} G E E_{t-j}+\sum_{j=1}^{k} \rho_{5} G E H_{t-j}+\varepsilon_{5, t}
$$

The variables remained as earlier defined. $\mathrm{K}$ represents the optimal lag length selected by the various lag length selection criteria. The stability of the variables was determined before we estimate the Vector Autoregressive (VAR).

This study used Nigerian annual data containing six variables viz;, government health expenditure (GEH), agricultural real GDP (AOP), government infrastructural expenditure; composed of construction, transport and communication (GEI), credit to agricultural sector (CRAS), and inflation (INFL) from 1981 to 2017. The data are secondary data obtained from government publications such as Central Bank of Nigeria Statistical Bulletin and National Bureau of Statistics.

\subsection{Results and Discussion}

\subsubsection{Summary Statistics}

The table presented below depicts the statistical attributes of the data used in this analysis. The variables include the real agricultural output (AOP), Government Expenditure on Health (GEH), Government Expenditure on Education (GEE), Government Expenditure on infrastructure; which include expenditures on transportation, construction and communication (GEI), Credit to Agricultural sector (CRAS) and Inflation rate (INFL). The mean of the variables as shown depicts a significant variation in terms of magnitude. Hence, estimation at levels may depict biasness in results.

The measure of normality revealed that three of the variables are leptokurtic; with values higher than the sample mean while three others are platykurtic with more values below the sample mean. Hence, Government expenditure on health, Credit to Agricultural Sector and Inflation all are leptokurtic and are peak curved. On the other hand, Government Expenditure on education, Government Expenditure on infrastructure and Real Agricultural output are all platykurtic with flatted curve. The skewness statistics showed that all the variables have higher values than the sample mean, long right tailed and asymmetric around the sample mean.

The Jarque-Bera Statistics revealed that the distributions of all the variables are not normal distribution. This 
is because the probabilities are highly statistically significant, hence the rejection of the null hypothesis of a normal distribution. A look at the maximum value suggests the presence of outliers as the real agricultural output and credit to agricultural sector have higher maximum values than other values in each observation.

Table 1: Summary Statistics of the Variables

\begin{tabular}{|c|c|c|c|c|c|c|}
\hline & AOP & GEH & GEE & GEI & CRAS & INFL \\
\hline Mean & 5711.869 & 58.85176 & 101.1884 & 47.61703 & 226.1162 & 19.89285 \\
\hline Median & 1426.974 & 15.22000 & 39.88000 & 8.020000 & 33.30000 & 13.67347 \\
\hline Maximum & 23952.55 & 257.7200 & 394.9000 & 209.0000 & 2012.300 & 76.75887 \\
\hline Minimum & 17.05218 & 0.040000 & 0.160000 & 0.120000 & 0.600000 & 0.223606 \\
\hline Std. Dev. & 7304.458 & 82.50639 & 134.0876 & 62.17432 & 531.8649 & 18.17895 \\
\hline Skewness & 1.099152 & 1.258756 & 1.175575 & 1.068108 & 2.868693 & 1.689937 \\
\hline Kurtosis & 2.860688 & 3.096540 & 2.846922 & 2.755148 & 9.633255 & 4.945482 \\
\hline Jarque-Bera & 7.480081 & 9.785251 & 8.558309 & 7.127699 & 118.5814 & 23.44636 \\
\hline Probability & 0.023753 & 0.007502 & 0.013854 & 0.028330 & 0.000000 & 0.000008 \\
\hline Sum & 211339.1 & 2177.515 & 3743.970 & 1761.830 & 8366.300 & 736.0356 \\
\hline Sum Sq. Dev. & $1.92 \mathrm{E}+09$ & 245062.9 & 647261.2 & 139163.2 & 10183688 & 11897.07 \\
\hline Observations & 37 & 37 & 37 & 37 & 37 & 37 \\
\hline
\end{tabular}

\subsubsection{Unit Root Test}

The unit root tests on all the variables in the model were carried out using the Augmented Dickey Fuller (ADF) test and Phillips-Perron (PP) test with intercept only and with trend to avoid spurious regression and the result are presented in Table 2. The results from both ADF and PP show that all the variables are stationary at first difference except inflation rate which is stationary at level.

Table 2: Unit Root Test

\begin{tabular}{|c|c|c|c|c|c|c|}
\hline \multicolumn{7}{|c|}{ Unit Root Test with Intercept without Trend } \\
\hline \multirow[t]{2}{*}{ Variables } & \multicolumn{3}{|c|}{ Augmented Dickey-Fuller } & \multicolumn{3}{|c|}{ Philip-Perron } \\
\hline & Level & $1^{\text {st }}$ difference & Remarks & Level & $1^{\text {st }}$ difference & Remarks \\
\hline LNAOP & $\begin{array}{l}-1.8915 \\
(0.3324)\end{array}$ & $\begin{array}{l}-3.8323^{*} \\
(0.0060)\end{array}$ & $\mathrm{I}(1)$ & $\begin{array}{l}-1.8915 \\
(0.3324)\end{array}$ & $\begin{array}{l}-3.8831^{*} \\
(0.0053)\end{array}$ & $\mathbf{I}(\mathbf{1})$ \\
\hline LNGEH & $\begin{array}{l}-1.3865 \\
(0.5764) \\
\end{array}$ & $\begin{array}{l}-9.8179 * \\
(0.0000)\end{array}$ & $\mathrm{I}(1)$ & $\begin{array}{l}0.8908 \\
(0.7799) \\
\end{array}$ & $\begin{array}{l}-17.9963^{*} \\
(0.0001)\end{array}$ & I(1) \\
\hline LNGEE & $\begin{array}{l}-1.9840 \\
(0.2920)\end{array}$ & $\begin{array}{l}-7.5565^{*} \\
(0.0000)\end{array}$ & $\mathrm{I}(1)$ & $\begin{array}{l}-1.2432 \\
(0.6448)\end{array}$ & $\begin{array}{l}-10.5556^{*} \\
(0.0000)\end{array}$ & I(1) \\
\hline LNGEI & $\begin{array}{l}-1.2030 \\
(0.6621)\end{array}$ & $\begin{array}{l}-8.3967^{*} \\
(0.0000)\end{array}$ & $\mathrm{I}(1)$ & $\begin{array}{l}-1.2477 \\
(0.6428)\end{array}$ & $\begin{array}{l}-9.6704 * \\
(0.0000)\end{array}$ & I(1) \\
\hline LNCRAS & $\begin{array}{l}-0.0373 \\
(0.9487) \\
\end{array}$ & $\begin{array}{l}-6.4244 * \\
(0.0000)\end{array}$ & $\mathrm{I}(1)$ & $\begin{array}{l}0.2089 \\
(0.9695)\end{array}$ & $\begin{array}{l}-6.6341^{*} \\
(0.0000)\end{array}$ & $\mathbf{I}(\mathbf{1})$ \\
\hline INFL & $\begin{array}{l}-4.9602 * \\
(0.0003)\end{array}$ & $\begin{array}{l}-9.0157^{*} \\
(0.0000)\end{array}$ & $\mathrm{I}(0)$ & $\begin{array}{l}-4.9615^{*} \\
(0.0003)\end{array}$ & $\begin{array}{l}-14.7940^{*} \\
(0.0000)\end{array}$ & $\mathbf{I}(\mathbf{0})$ \\
\hline \multicolumn{7}{|c|}{ Unit Root Test with Intercept and Trend } \\
\hline LNAOP & $\begin{array}{l}0.0020 \\
(0.9947)\end{array}$ & $\begin{array}{l}-3.5177 * \\
(0.0452)\end{array}$ & $\mathrm{I}(1)$ & $\begin{array}{l}-0.3072 \\
(0.9873)\end{array}$ & $\begin{array}{l}-3.9566^{*} \\
(0.0199)\end{array}$ & I(1) \\
\hline LNGEH & $\begin{array}{l}-0.0240 \\
(0.9941) \\
\end{array}$ & $\begin{array}{l}-5.1417^{*} \\
(0.0012) \\
\end{array}$ & $\mathrm{I}(1)$ & $\begin{array}{l}-3.9129^{*} \\
(0.0217) \\
\end{array}$ & $\begin{array}{l}-20.6665 \\
(0.0000) \\
\end{array}$ & I(1) \\
\hline LNGEE & $\begin{array}{l}-3.1991 \\
(0.1006)\end{array}$ & $\begin{array}{l}-5.6130 * \\
(0.0003) \\
\end{array}$ & $\mathrm{I}(1)$ & $\begin{array}{l}-3.1790 \\
(0.1046) \\
\end{array}$ & $\begin{array}{l}-13.3457 \\
(0.0000) \\
\end{array}$ & I(1) \\
\hline LNGEI & $\begin{array}{l}-2.9721 \\
(0.1537)\end{array}$ & $\begin{array}{l}-8.4027^{*} \\
(0.0000)\end{array}$ & $\mathrm{I}(1)$ & $\begin{array}{l}-2.9370 \\
(0.1635)\end{array}$ & $\begin{array}{l}-11.5944 \\
(0.0000)\end{array}$ & I(1) \\
\hline LNCRAS & $\begin{array}{l}-2.1776 \\
(0.4871) \\
\end{array}$ & $\begin{array}{l}-6.3688 * \\
(0.0000) \\
\end{array}$ & $\mathrm{I}(1)$ & $\begin{array}{l}-2.2141 \\
(0.4678) \\
\end{array}$ & $\begin{array}{l}-6.5754 * \\
(0.0000) \\
\end{array}$ & I(1) \\
\hline INFL & $\begin{array}{l}-4.9507 * \\
(0.0016)\end{array}$ & $\begin{array}{l}-8.8754 \\
(0.0000)\end{array}$ & $\mathrm{I}(0)$ & $\begin{array}{l}-4.9528^{*} \\
(0.0016)\end{array}$ & $\begin{array}{l}-14.3738 \\
(0.0000)\end{array}$ & $\mathbf{I}(\mathbf{0})$ \\
\hline
\end{tabular}

* represent stationarity at levels and first difference respectively. 


\subsubsection{Optimal Lag Length Selection}

The length of the structural lag system for the model was determined empirically using the various information criteria and the result is presented in Table 3. The result predicts optimal lag length of one based on Sequential Modified LR Test Statistic, Final Prediction Error, and Schwarz Information Criterion. Hannan-Quinn Information Criterion and Akaike Information Criterion on the other hand selected a lag length of four. To confirm the optimal lag length, test of stability was conducted on the predicted optimal lag lengths using inverse roots of AR characteristic polynomial and the result shows that the predicted optimal lag length of one is stable for model estimation. The result of the stability test for the optimal lag length of one is presented on Table 4.

Table 3: Selection of Lag length Criteria

\begin{tabular}{|c|c|c|c|c|c|c|}
\hline LAG & LOGL & LR & FPE & AIC & SC & HQ \\
\hline $\mathbf{0}$ & -296.6206 & NA & 3.719142 & 18.34064 & 18.61274 & 18.43219 \\
\hline $\mathbf{1}$ & -153.1773 & $226.0319^{*}$ & $0.005747^{*}$ & 11.82893 & $13.73357^{*}$ & 12.46978 \\
\hline $\mathbf{2}$ & -117.8242 & 42.85222 & 0.007529 & 11.86814 & 15.40533 & 13.05830 \\
\hline $\mathbf{3}$ & -76.83905 & 34.77530 & 0.011140 & 11.56600 & 16.73576 & 13.30547 \\
\hline $\mathbf{4}$ & -4.455369 & 35.09512 & 0.007664 & $9.360931^{*}$ & 16.16324 & $11.64970^{*}$ \\
\hline
\end{tabular}

Table 4: Roots of Characteristic Polynomial - Lag Length Stability Test

\begin{tabular}{|c|c|}
\hline Root & Modulus \\
\hline 0.990935 & 0.990935 \\
\hline 0.909123 & 0.909123 \\
\hline $0.598791-0.486908 \mathrm{i}$ & 0.771770 \\
\hline $0.598791+0.486908 \mathrm{i}$ & 0.771770 \\
\hline $0.154248-0.711582 \mathrm{i}$ & 0.728108 \\
\hline $0.154248+0.711582 \mathrm{i}$ & 0.728108 \\
\hline 0.692214 & 0.692214 \\
\hline$-0.481818-0.339303 \mathrm{i}$ & 0.589300 \\
\hline$-0.481818+0.339303 \mathrm{i}$ & 0.589300 \\
\hline-0.417210 & 0.417210 \\
\hline $0.140762-0.107794 \mathrm{i}$ & 0.177295 \\
\hline $0.140762+0.107794 \mathrm{i}$ & 0.177295 \\
\hline \multicolumn{2}{|c|}{ No root lies outside the unit circle. } \\
\hline \multicolumn{2}{|c}{} \\
\hline
\end{tabular}

\subsubsection{Error Correction Form}

To investigate the short and long run relationship among the variables, the ARDL technique selected ARDL model $(1,1,2,2,0,0)$. The coefficient of the error correction term as reported below is negative and statistically significant. It is the speed of adjustment towards long run equilibrium and shows that $20 \%$ of the disequilibrium will be corrected periodically in order to achieve stability and long run equilibrium. This is presented in Table 5 .

TABLE 5:ERROR CORRECTION FORM RESULT

\begin{tabular}{|c|c|c|c|}
\hline \multicolumn{4}{|c|}{ ERROR CORRECTION MODEL REGRESSION RESULT } \\
\hline VARIABLE & COEFFICIENT & T-STATISTIC & PROBABILITY \\
\hline CointEq(-1) & -0.200109 & -9.442958 & 0.0000 \\
\hline R-Squared & 0.595203 & & \\
Adjusted R-Squared & 0.541230 & & \\
\hline
\end{tabular}

\subsubsection{ARDL Bound Test}

The bounds test is anchored on the joint F-statistic. Its asymptotic distribution is non-standard under the null hypothesis of no cointegration. The existence of long run relationship in the model is determined when the null hypothesis of no cointegration is rejected when the value of the test statistic exceeds the upper critical bounds value, while it is accepted if the F-statistic is lower than the lower bounds value. On the other hand however, the cointegration test is inconclusive. The bound test in this study as revealed in the Table below shows that there exists a long run relationship among the variables because the F-statistics (10.19079) is actually higher than the upper bound critical value (4.15) at $1 \%$ level of significance. This implies the rejection of the null hypothesis of no cointegration among the variables.

Table 6: ARDL Bound Test

\begin{tabular}{|l|l|l|l|l|l|}
\hline \multicolumn{5}{|c|}{ Critical value Bounds } & \multirow{2}{*}{ F-Statistics } \\
\cline { 1 - 4 } & $\mathbf{1 0 \%}$ & $\mathbf{5 \%}$ & $\mathbf{2 . 5 \%}$ & $\mathbf{1 \%}$ & \multirow{2}{*}{$\mathbf{1 0 . 1 9 0 7 9}$} \\
\cline { 1 - 4 } Upper Bound I(0) & 2.08 & 2.39 & 2.70 & 3.06 & \\
\hline Lower Bound I(1) & 3.00 & 3.38 & 3.73 & 4.15 & \\
\hline
\end{tabular}




\subsection{SHORT RUN EFFECT OF GOVERNMENT EXPENDITURE COMPONENTS ON AGRICULTURAL PRODUCTIVITY IN NIGERIA}

From the short run result obtained, the previous value of agricultural output revealed a positive and significant effect on the current value of agricultural output in Nigeria. A percentage increase in the previous value of agricultural output increases current output by $0.7998 \%$ at less than $5 \%$ level of significance. This revealed an increase in agricultural output in Nigeria. Government educational Expenditure has an insignificant negative effect on Real Agricultural Output in the short run. Thus, a percentage increase in government education expenditure leads to a 0.005 percentage reduction in agricultural output in Nigeria. This shows that lesser attention is paid to farmer and agriculture related education in Nigeria despite the huge yearly budget on education. Also, academic institutions no longer take practical agricultural trainings seriously as most training are more theoretical with little or no practical implementation. The result revealed a disconnection between agricultural knowledge acquisition and its implementation as the classroom environment is quite different from what is obtainable on the fields.

Government health-related expenditure also has a positive and non-significant effect on agricultural output in the current period. A percentage increase in health related expenditures results into 0.023 percent increase in agricultural productivity. This shows that given an improvement in farmers' inclusion as beneficiaries of various health-related government programs in Nigeria, there will be an improvement in agricultural productivity. Similarly, the two previous periods also depicts a positive effect on agricultural output. Even though an improvement in farmers' health determines the level of agricultural productivity, the contribution of government expenditure to this is insignificant in Nigeria as most famers are based in the rural areas with little or no health care considerations. Government expenditure on infrastructure also share similar effect on agricultural productivity as a percentage increase in government infrastructure-related expenditure leads to a 0.09 percentage increase in agricultural output. This show a gradual improvement in needed infrastructure for agricultural enhancement in the rural areas. The previous value of infrastructural contribution to agricultural output growth also signifies a positive relationship while the value for two previous periods show a significant decay in infrastructural facilities as they are not rightly provide as at when and where it is needed, resulting to a negative relationship. Good roads are mostly concentrated in urban areas while the rural areas where they are critically needed for the movement of agricultural produce are left unattended, hence the negative relationship.

Also, Credit to Agricultural sector has a non-significant positive effect on Real Agricultural Output in the short run and a positive insignificant long run period. Hence, an increase in credit availability for agricultural finances improves agricultural output in both the short and long runs. Furthermore, inflation has a positive and significant effect on Real Agricultural Output in the short run and a positive but insignificant effect in the long run period.

TABLE 7: Short Run Result Presentation

\begin{tabular}{|c|c|c|c|}
\hline VARIABLE & COEFFICIENT & T-STATISTIC & PROB. VALUE \\
\hline LNAOP(-1) & 0.799891 & 8.192236 & $0.0000^{*}$ \\
\hline LNGEE & -0.044826 & -0.544678 & 0.5910 \\
\hline LNGEH & 0.022777 & 0.280143 & 0.7818 \\
\hline LNGEH(-1) & 0.035985 & 0.719375 & 0.4789 \\
\hline LNGEH(-2) & 0.119515 & 2.403268 & $0.0243^{* *}$ \\
\hline LNGEI & 0.093160 & 2.049321 & $0.0515^{* * *}$ \\
\hline LNGEI(-1) & 0.084389 & 1.495803 & 0.1477 \\
\hline LNGEI(-2) & -0.146105 & -2.621609 & $0.0150^{* *}$ \\
\hline LNCRAS & 0.000389 & 0.010826 & 0.9915 \\
\hline INFL & 0.006694 & 4.399014 & $0.0002^{*}$ \\
\hline C & 1.169321 & 2.381277 & \\
\hline R-Squared & 0.998 & & 0.0000 \\
\hline Adjusted R-Squared & 0.997 & & \\
\hline F-statistic & 1351.51 & Prob & \\
\hline Durbin-Watson stat & 1.67 & & \\
\hline
\end{tabular}

$*, * *$, and $* * *$ indicate level of significance at $1 \%, 5 \%$ and $10 \%$ respectively.

\subsection{LONG RUN EFFECT OF GOVERNMENT EXPENDITURE COMPONENTS ON AGRICULTURAL PRODUCTIVTY IN NIGERIA}

The estimated coefficients of the long run relationship are insignificant for government expenditure on education (GEE), government expenditure on health (GEH), government expenditure on infrastructure (GEI), credit to agricultural sector (CRAS) and inflation (INF) at 5\% level of significant. Government Expenditure on Education (GEE) has a negative impact on Agricultural Output. The other variables which include Government Expenditure on Infrastructure and Credit to Agricultural Sector all have positive but insignificant impact Agricultural Output. 
This result supports the short run result indicating the poor contribution of education to agricultural growth in Nigeria. This further buttress the lack of interest of the youths in agriculture related ventures due to inadequate farm mechanization. On the other hand, government expenditure on health, Infrastructure, and loans for agricultural expansion in Nigeria all positively influence agricultural productivity. Considering the impact of government health and infrastructure expenditure, they are insignificant at 5\% probability but have a positive effect on agricultural output. This shows that the increase in government expenditure on health and infrastructure have not aided agricultural output significantly in Nigeria. This indicates that despite the increase in government expenditures on them, they have not reflected significantly on agricultural productivity in the country. This might be due to divertive ways common to the use of public funds in Nigeria. Also, the $0.002 \%$ contribution of credit and loans to industrial productivity is not significant at 5\% level of significance. This is evident most agricultural loans can only be sourced from government backed financial institutions while private organizations will request for much collateral provision before loan provision. Hence, the absence of government assistance and the lack of collateral assets restrict loan acquisition for agricultural finance. Inflation is also insignificant at 5\% level and has a positive impact on agricultural output. Thus, increasing prices of goods and services have positive impact prices of agricultural products thereby leading to increased agricultural output.

Table 8: Estimated long run coefficients using the ARDL approach

\begin{tabular}{|l|l|l|l|}
\hline VARIABLE & COEFFICIENT & T-STATISTICS & P-VALUE \\
\hline LNGEE & -0.224007 & -0.489397 & 0.6290 \\
\hline LNGEH & 0.890901 & 1.741450 & $0.0944 * * *$ \\
\hline LNGEI & 0.157132 & 0.467106 & 0.6446 \\
\hline LNCRAS & 0.001945 & 0.010838 & 0.9914 \\
\hline INFL & 0.033449 & 1.823359 & $0.0807 * * *$ \\
\hline C & 5.843422 & 8.766301 & 0.0000 \\
\hline
\end{tabular}

$*, * *$, and $* * *$ indicate level of significance at $1 \%, 5 \%$ and $10 \%$ respectively.

\subsection{Stability Diagnostics}

The Breusch-Godfrey serial correlation test shows that the estimated model is free from serial correlation problems $(f=1.9927, p>0.05)$. Similarly, the Heteroscedasticity test which is reported in this study affirms that the model is free from any heteroscedastic problem as all its probabilities are not significant at 5\%. Also, the CUSUM and CUSUMSQ tests revealed that the variables are stable and within the boundary.

Table 9: Diagnostic Tests Result

\begin{tabular}{|c|c|c|}
\hline & F - statistic & Probability \\
\hline Breusch-Godfrey Serial Correlation test & 0.958269 & 0.34 \\
\hline White Heteroskedasticity test (ARCH) & 0.245575 & 0.62 \\
\hline Jarque-Bera test & 3.491853 & 0.18 \\
\hline Ramsey RESET Test (log likelihood ratio) & 2.814691 & 0.08 \\
\hline
\end{tabular}

Fig 1: CUSUM Test Result

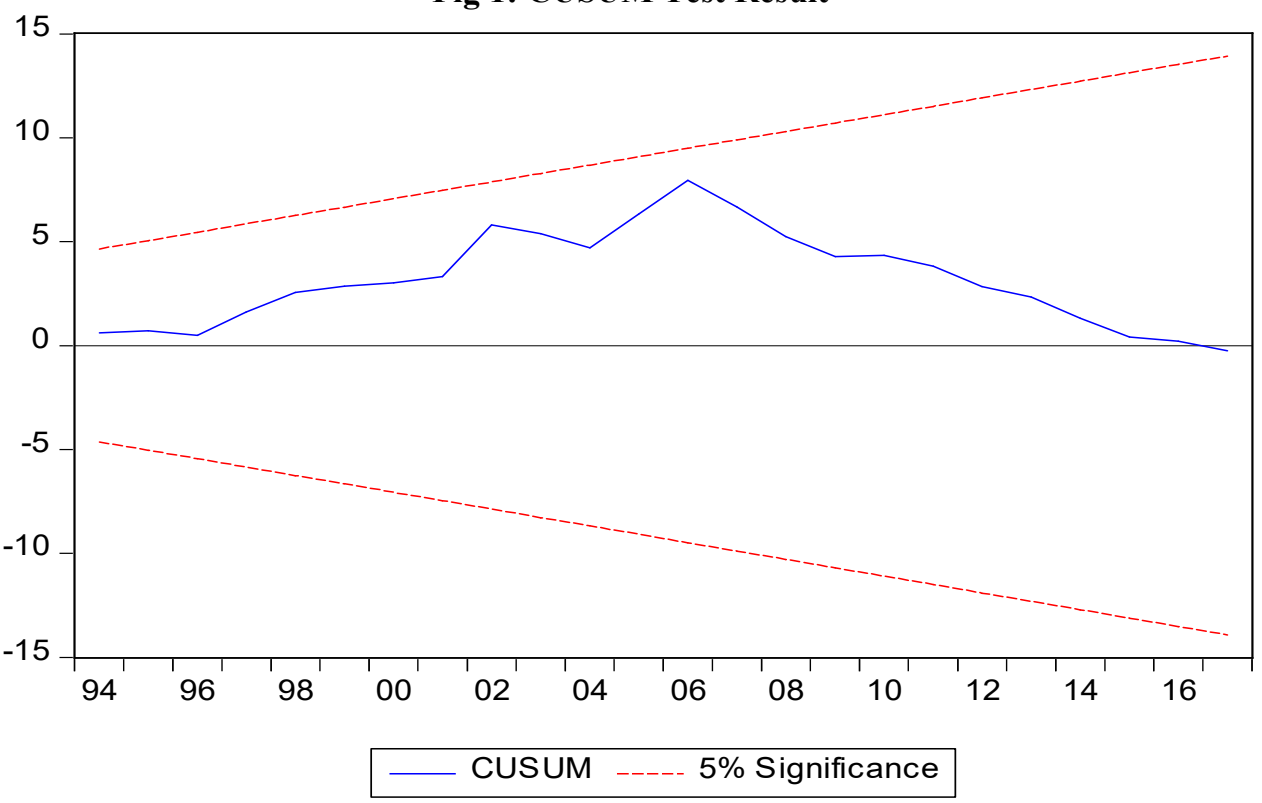


Fig 2: CUSUM of Square Test result

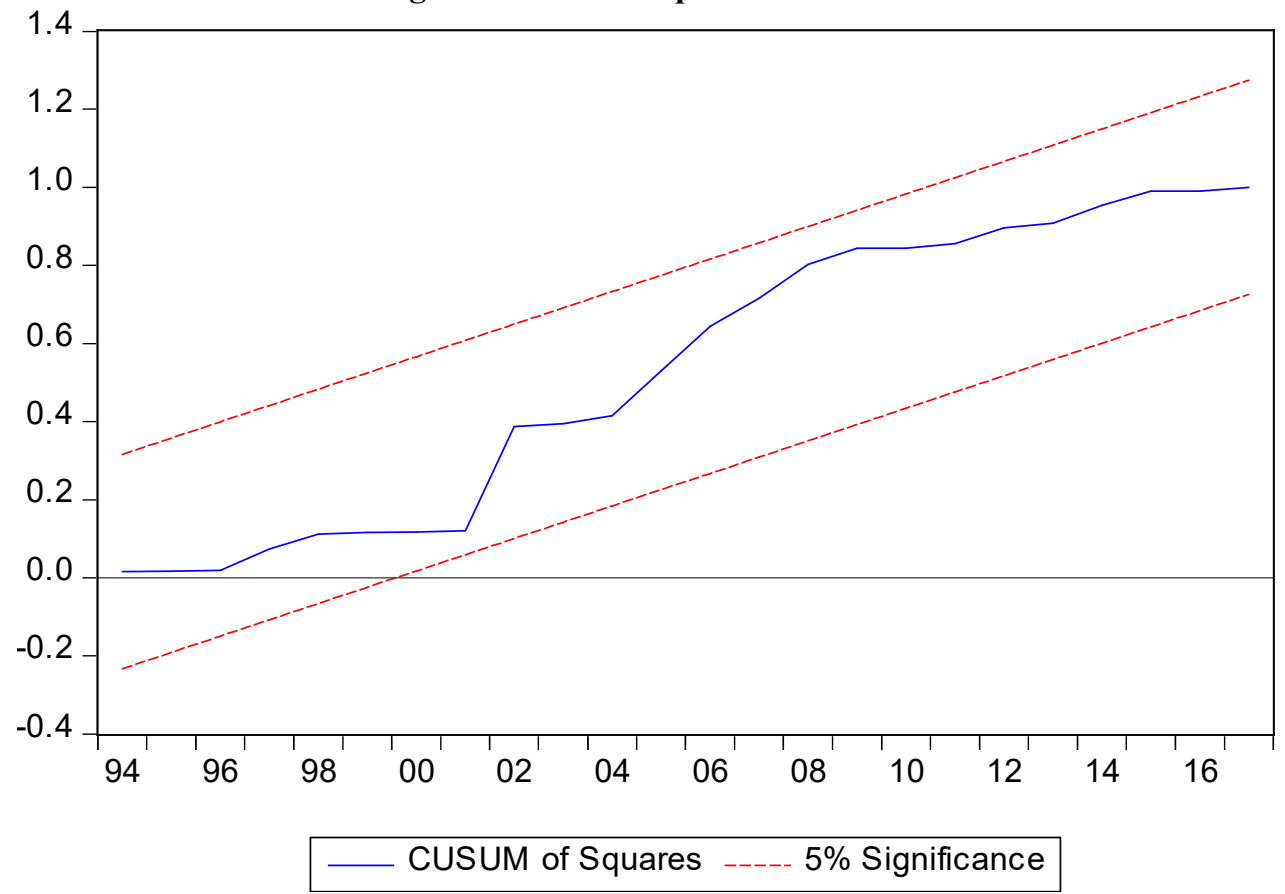

\subsection{Causality Test}

In line with the objective of this study which is to examine the existence of causal relation between government spending components and agricultural output in Nigeria, the causality test was done and the result shows that exists a uni-directional causal relationship from Government Expenditure on Education (GEE), government Expenditure on Health (GEH) and Government Expenditure on Infrastructure (GEI) to Agricultural productivity (AOP) in Nigeria. This means that the various government expenditure components have causal relationships with Agricultural productivity. Thus, an improvement in the level of government expenditure on this various components can lead to improved agricultural output while negative shocks to these variables hampers the growth of agricultural sector. However a reduction in government budgetary performance especially government expenditure could adversely affect agricultural output. Also, a uni-directional causal relationship was found between Government Expenditure on Education (GEE) and Government Expenditure on Health (GEH). Also, Government Expenditure on Health (GEH) and Government Expenditure on Infrastructure (GEI) have unidirectional causal relationship. This finding is novel because the knowledge of significant causal relationship between government expenditure variables and agricultural output could shift policy implementation to those that favors the agriculture sector; being the most primary source of growth and the bedrock of development.

\section{Table 10: Causality Test}

\begin{tabular}{|c|c|c|c|c|c|}
\hline $\begin{array}{c}\text { Dependent } \\
\text { Variables }\end{array}$ & \multicolumn{5}{|c|}{ Independent Variables } \\
\cline { 2 - 6 } AOP & AOP & GEE & GEH & GEI & CRAS \\
\hline GEE & - & 9.089 & 13.018 & 14.050 & 0.097 \\
& & $(0.0026)^{*}$ & $(0.0003)^{*}$ & $(0.0002)^{*}$ & $(0.7558)$ \\
\hline GEH & 0.0013 & - & 0.542 & $6.39 \mathrm{E}-05$ & 0.133 \\
& $(0.9715)$ & & $(0.4618)$ & $(0.9936)$ & $(0.7149)$ \\
\hline GEI & $(0.170$ & 11.12 & - & 1.356 & 0.208 \\
& $(0.0601)$ & $(0.0009)^{*}$ & & $(0.2442)$ & $(0.6482)$ \\
\hline CRAS & $0.7028)$ & $(0.0004)^{*}$ & $(0.0019)^{*}$ & - & 0.076 \\
& $(0.4023)$ & 0.007 & 0.124 & 0.504 & $(0.7833)$ \\
\hline
\end{tabular}

$*, * *$, and $* * *$ denotes significance at $1 \%, 5 \%$ and $10 \%$ level of significance.

\subsection{Conclusions and Policy Implications}

The results obtained and analysed above depicts that most government expenditures are insignificant and as such are ineffective in promoting agricultural productivity in Nigeria in short and the long run periods. This is indicative of the decay on the nation's institutional arrangement which allows allocation of funds for government projects 
but does not provide adequate mechanism for implementation monitoring, reporting and auditing. Even, most individual saddle with the responsibility of carrying out the above mentioned tasks only aim after satisfying selfish interests. Hence, the ineffectual state of government expenditures on the citizenry. This poor state of education, infrastructure and health all directly affects agricultural productivity as they determine the living standard of the citizens, majority of whom poor and are farmers in Nigeria. Hence, there seems a need for proper implementation and effective monitoring of government's yearly budgetary estimates and ensuring strict compliance to the process of budget implementation becomes highly important. In the light of the above, this study recommended that;

Government should make a concerted effort at encouraging the private sector of the economy to increase its investment in Agricultural sector by providing good infrastructure, avoiding policy inconsistency and unnecessary intervention by government institutions which have no controlling relationship with the firms as this could send wrong signal to the private sector. Also, as it is seen that government expenditure on health positively influence agricultural productivity, adequate access to free health services is recommended for farmers especially as this will improve productivity and encourage youth participation in agriculture.

Government should intensify efforts on encouraging the financial institutions to make a viable percentage of their total credit facility available for agricultural sector. Also, Government should ensure that credit is made available to peasant's farmers at relatively low interest rate as this could help boost Real Agricultural Output.

The need to restructure and completely overhaul the various government institutions and agencies responsible for implementation, revenue collection and monitoring of government project as it relates to its agriculture to allow for transparency and effective management strategies as this will help ensure a more efficient use of the little available resources for growth financing. Finally, private audit process is recommended to audit various government finances at the year ending before the implementation of another year's budget as this will give room for more transparency and a more responsible use of government resources in Nigeria.

\section{REFERENCES}

Abayomi O. (1997). The Agricultural Sector in Nigeria: The way forward. CBN Bullion. 21: 14-25.

Adeolu B. A., \& Bamire S. (2004) Direct Foreign Investment and Firm-level Productivity in the Nigerian Agro/agro-allied Sector, Journal of Social Sciences, 9:1, 29-36; https://doi.org/10.1080/09718923.2004.11892427.

Adofu I., Abula M., and Agama J. E. (2012) The effects of government budgetary allocation to agricultural output in Nigeria, Sky Journal of Agricultural Research Vol. 1(1), pp. 1 - 5, http://www.skyjournals.org/SJAR

Aigbokan, B. E. (2001). Resuscitating Agricultural Production (Cocoa, Cotton, Groundnut, Palm-Oil, Rubber etc) for Exports. CBN Proceedings of the $10^{\text {th }}$ Annual Conference of the Zonal Research Unit, Ibadan, April 13 to $16,2001$.

Akeem A. T., Oluwemino O., \& Olayinka I. B. (2015) Public sector expenditure in agriculture and economic growth in Nigeria: An empirical investigation, Agrekon, 54:2, 76-92, DOI: 10.1080/03031853.2015.1073000.

Akinboyo, O. L. (2008). Five decades of Agricultural Policies. What role has statistics played? CBN Bullion, 22 : 134-165.

Amassoma, D., Nwosa, P., and Ajisafe, R. A. (2011) “Components of Government Spendingand Economic Growth in Nigeria'": An Error Correction Modelling. Journal of Economics and Sustainable Development

Ani D. P, Biam C. K, Kantiok M. (2014) 'Patterns and Impact of Public Expenditure on Agriculture: Empirical Evidence from Benue State, Nigeria'; Journal of Agricultural \& Food Information, 15:4, 311-323, DOI: $10.1080 / 10496505.2014 .958933$

Anyanwu, et al (1997). The structure of the Nigerian Economy (1960-1997). Onitsha Joanee

Armas E.B., et al., (2012). Agriculture Public Spending and Growth in Indonesia. The world Bank, East Asia Region, Poverty Reduction and Economic Management Unit. Policy Research Working Paper No. 5977.

Ayoola G.B \&Oboh V.U. (2000). A Model of Public Expenditure to Reveal the Preference for Agriculture in the Budget. Journal of rural Economic Development., 14(1): 56-73.

Barro, R. and Sala-i-Martin X., (1992). "Public Finance in Models of Economic Growth", Review of Economic Studies. Vol. 59, p.645-661.

Barro, R., (1990). “Government Spending in a simple model of Endogenous Growth. ” Journal of Political Economy. Vol. 98, No.5 p.103-125.

Benson U. O. (2012) "Institutions, Macroeconomic policy and the Growth of the Agricultural sector in Nigeria" Global Journal of Human Social Sciences, Volume 12, Issue 2249-460X version 1.0

Binswanger H. P \& Townsend S. R. (2000). The Growth Performance of Agriculture in Sub-Saharan Africa. American Journal of agricultural Economics., 82(5): 1075-1086.

Binuomote, S. O. (2012) "Effect of Government Expenditure on Agricultural Productivity in Nigeria (1960-2008). A Bounds Testing Approach. Continental Journal of Agricultural Science 6 (2): 30 - 37 Wilolud Journal ISSN: $2141-420$

CAADP. (2003). Comprehensive Africa Agriculture Development Programme Framework for Food Security and 
Poverty Reduction in Africa. http//www.nepad-caadp.net.
CBN (2009)
Central
Bank
of
Nigeria
Statistical
Bulletin. www.cenbank.org/out/2010/publications/statisticalbulletins/2009/index.hmtl

Chalermpon, J. (2011). "Does A Long-Run Relationship Exist between Agriculture and Economic Growth in Thailand?" International Journal of Economics and Finance. ISSN: 1916-9728 Vol. 3, No. 3; August, Pp 227228 .

Chavas, J. (2001). An International Analysis of Agricultural Productivity. FAO Corporate Document Repository, Economic and Social development Department, 2001.

DFID, (2005). Growth and Poverty Reduction. The Role of Agriculture. Policy Paper, Ibadan University Press, Nigeria.

Diao X. et al., (2009). Agricultural Growth and Investment Options for Poverty Reduction in Nigeria. Development Strategy and Governance Division, International Food Policy Research Institute (IFPRI) and ReSAKSS West Africa, International Institute of Tropical Agriculture (IITA).

Easterly, W \&Rebelo, S (1993). "Fiscal Policy and Economic Growth: An Empirical Investigation”. Journal of Monetary Economics, 32(2) 417-458.

Eyo Emmanuel O. (2008) Macroeconomic Environment and Agricultural Sector Growth in Nigeria, World Journal of Agricultural Sciences 4 (6): 781-786, 2008 ISSN 1817-3047

Fan S. \& Saurka A. (2008). Tracking Agricultural Spending for Agricultural Growth and Poverty Reduction in Africa. ReSAKSS Issue Brief No. 5. Washington DC.

Fan S. et al., (2000). Government Spending, Agricultural Growth and Poverty in India. American Journal of Agricultural Economics, 82(4): 1038-1051.

Fan S. et al., (2009). Public Spending for Agriculture in Africa. Regional Strategic Analysis and Knowledge Support System (ReSAKSS) working paper No. 28, www.resakss.org/index.php.pdf $=42375$.

Folster, S \&Henrekson, M. (1999). Growth Effects of Government Expenditure and Taxation in Rich Countries. European Economics Review., 45(8) : 1501-1520.

Fulginiti, L.E and Perrin, R.K. (1998). Agricultural Productivity in Developing Countries. Elsevier Science B.V. Agricultural Economics, 19(1998), Pp 45-51.

Garba K.P., (1998) is Government Expenditure Volatility Harmful for Growth.

Grant, O.W. (2002). Productivity in German Agriculture: Estimates of Agricultural Productivity from Regional Accounts for 21 German Regions: 1880/4, 1893/7, 1905/9. University of Oxford, Discussion Paper in Economic and Social History, no. 47, August.

Hammond, R. (2003). The Impact of IMF Structural Adjustment Policies on Tanzanian Agriculture. http/www.developmentgap.org/imftanzania.html.

Heilleiner, G.K. (1996). Peasant Agriculture: Government Economic Development in Nigeria. In: Irwin, I., Edwin, P.A (Eds.): Agricultural Growth in Nigeria. Calabar. University of Calabar, Pp 34-55.

Iganiga B.O; Unemhilin D.O (2017) the Impact of Federal Government Agricultural Expenditure on Agricultural Output in Nigeria; Journal of Economics, 2:2, 81-88, DOI: 10.1080/09765239.2011.11884939. https://doi.org/10.1080/09765239.2011.1188499.

Ijaiya G.T (2000). Economic Growth in Nigeria, An Asymmetry of the Baalanced Growth Doctrine. In Usman A and Ijaiya G.T (eds). Selected Essays on the Contradictions of Economic Development Theories in Nigeria. Ilorin: Haytee Publishing Co. ISSN 2222-170 (Paper) ISSN 2222-2855 (Online)Vol.2, No.4, 2011

Iwayemi A. (1994). Perspectives and Problems of Economic Development in Nigeria: 1960-1990. Ibadan: CEAR.

Kelechi, I., and Cynthia, E. (2011) "Determinants of Agricultural Output: implication on government funding of agricultural sector in Abia State, Nigeria' Journal of Economics and Sustainable Development ISSN $2222-$ 1700 (Paper) ISSN 2222-2855 (Online)Vol.2, No.4,

Kiani, A.K., et al., (2008). Total Factor Productivity and Agricultural Research Relationship: Evidence from Crops Sub-Sector of Pakistani's Punjab. European Journal of Science Research, Vol. 23 No. 1, 2008, Pp. 87-97.

Loto, M.A., (2011). "Impact of government sectoral expenditure on economic growth in Nigeria" Journal of Economics and International Finance Vol. 3(11), pp. 646- 652.

Mogues T. et al., (2008). Agriculture Spending in Nigeria. International Food Policy Research Institute (IFPRI) Discussion Paper 789, Washington, DC. U.S.A.

Nwosu, A.C. (2004). Private Sector Initiative in Agricultural development in Nigeria. CBN proceedings of the $13^{\text {th }}$ Annual Conference of the Regional Research Unit. University of Ibadan, August 6 to 8, 2004.

Oji-Okoro, I.(2011)" Analysis of the Contribution of Agricultural Sector on the Nigerian Economic Development" World Review of Business Research Vol. 1. No. 1. March 2011. Pp. 191 - 200

Okadim, I.A. and Albert C.O. (2012) "Analysis of the Effects of Monetary and Fiscal Policy Indicators on Agricultural Output (Cereal)"' (1990-2000). Journal of Research in Agriculture 1: 058-064

Olajide, O.T., et al., (2011) "Agriculture Resource and Economic Growth in Nigeria"' European Scientific 
Journal October edition vol. 8, No.22 ISSN: 1857 - 7881 (Print) e - ISSN 1857- 7431103

Pesaran, M.H and Pesaran, B (1997) Working with Microfit 4.0: Interactive Econometric Analysis. Oxford University Press, Oxford.

Pesaran, M.H., Shin, Y., Smith, R.J., (2000). Structural analysis of vector error correction models with exogenous I(1) variables. Journal of Econometrics 97, 293-343.

Pesaran, M.H., Shin, Y., Smith, R.J., (2001). Bounds testing approaches to the analysis of level relationships. Journal of Applied Economics 16, 289-326.

Poonyth, D., et al., (2001). Is Agricultural Sector Growth a precondition for Economic Growth? The case of South Africa. Agrekon, Vol. 40, No. 2, June, Pp 269-278.

Shenggen Fan (2008) Public Expenditures, Growth and Poverty: Lessons from Developing Countries. Published for the International Food Policy Research Institute; The John Hopkins University Press, Baltimore.

Suleiman G. P., and Aminu U. (2012) "Global Food Crisis: Public Capital Expenditure and Agricultural Output in Nigeria"' Journal of Food Research Vol. 1, pp 286-292

Tripathi, A and Prasad, A.R. (2008). Agricultural Productivity Growth in India. Journal of Global Economy An International jounal, ISSN : 0975-3931, 2008.

Velazco, J. (2001). Agricultural Production in Peru (1950-1995): Sources of Growth. FAO Corporate Document Repository, Economic and Social Development Department, 2001.

Vida A., et al., (2009) “Agricultural Investment for Growth and Poverty Reduction in Nigeria" International Food Policy Research Institute (IFPRI) and ReSAKSS-West Africa International Institute of Tropical Agriculture (IITA). Pp 1-22

Wiebe, K.D., et al., (2001). Agricultural Policy, Investment and Productivity in Sub-Saharan Africa. FAO Corporate Document Repository, Economic and Social Development Department, 2001.

Yesufu T.M. (1996),. The Nigerian Economy Growth without Development. Benin: Benin Social Sciences Series for Africa.

Zepeda, L. (2001). Agricultural Investment, Production Capacity and Productivity. FAO Corporate Document Repository, Economic and Social Development Department, 2001. 